\title{
ПИТАННЯ РОЗМЕЖУВАННЯ АДМІНІСТРАТИВНО-ПРАВОВИХ ВІДНОСИН ВІД ПРИВАТНОПРАВОВИХ, ЩО ВИНИКАЮТЬ У СФЕРІ ПУБЛІЧНОГО АДМІНІСТРУВАННЯ ІНВЕСТИЦІЙНОї ДІЯЛЬНОСТІ
}

\section{Жуков М. С.}

\section{ВСТУП}

Питання розмежування адміністративно-правових відносин від приватноправових у сфері публічного адміністрування інвестиційної діяльності має велике значення. На практиці трапляються випадки, коли складно визначити, які саме відносини виникають між органом державної влади, місцевою державною адміністрацією і юридичною особою під час укладання інвестиційних договорів. Ще складнішим виглядає питання, стосовно того, які договори у сфері інвестиційної діяльності, однією зі сторін за якими $є$ суб’єкт публічної адміністрації, належать до адміністративних, а які до господарських.

Наслідком неправильного визначення правової природи правовідносин, зокрема i тих, що виникають за результатом укладання договору, стає порушення правил юрисдикції під час звернення до суду. До прикладу помилкового умовиводу можна віднести ситуацію, коли, уклавши договір із суб'єктом публічної адміністрації, друга сторона (юридична особа приватного права) з метою захисту свого порушеного права звертається до адміністративного суду, виходячи 3 того, що одна сторона наділена державно-владними повноваженнями, а отже, сам спір має всі ознаки публічно-правового. Розмежування відносин за суб'єктом $є$ однією 3 найбільш поширених помилок.

Водночас більш загрозливі наслідки неправильного визначення правової природи відносин виражаються в порушенні самими судами правил юрисдикції, що, у свою чергу, є обов'язковою підставою для скасування рішення суду із закриттям провадження.

Ураховуючи зазначене, 3 метою запобігання порушенням правил юрисдикції судів необхідне однозначне і точне розуміння правової природи тих чи інших відносин, що виникають у сфері публічного адміністрування інвестиційної діяльності. Першочерговим є розуміння відмінності приватного права від публічного. 


\section{1. Розмежування публічних та приватних правовідносин}

Відсутність єдиної усталеної теорії розмежування норм публічного та приватного права у вітчизняній науці насамперед пов'язана 3 тим, що тривалий час поділ права на приватне та публічне заперечувався.

Радянська правова доктрина не сприймала ідею дуалізму соціалістичного права, виходячи з відомого висловлювання Володимира Леніна про те, що «ми нічого «приватного» не визнаємо, для нас усе в галузі господарства $\epsilon$ публічно-правовим, а не приватним». ${ }^{1}$ Водночас, 3 огляду на відсутність у Союзі Радянських Соціалістичних Республік (далі- СРСР) спеціалізованих судів, зокрема адміністративних, такий поділ не мав i практичного сенсу, оскільки у СРСР не виникало необхідності пошуку відповіді на питання про те, якому суду підвідомча та чи інша справа. 3 огляду на це на момент початку функціонування в Україні адміністративних судів українська правнича наука виявилася неготовою задовольнити потреби українського судочинства у сфері розмежування публічного (адміністративного) та приватного права. ${ }^{2}$

Наслідком цього стала поява численних наукових робіт, у яких зазначалось, що основним критерієм розмежування є суб'єкт. Виходячи зі змісту такої теорії, якщо відносини виникали між державою та фізичною особою чи юридичною особою приватного права, вони ставали адміністративно-правовими.

Такі теорії помилкові, оскільки суб'єкт публічної адміністрації може бути учасником приватноправових відносин. Нормативним підтвердженням цього є ч. 2 ст. 2 Цивільного кодексу України ${ }^{3}$, відповідно до якої учасниками цивільних відносин є: держава Україна, Автономна республіка Крим, територіальні громади, іноземні держави й інші суб'єкти публічного права. Відповідно до ст. ст. 170-172 Цивільного кодексу України, держава набуває і здійснює цивільні права й обов'язки через органи державної влади, Автономна Республіка Крим - через органи влади Автономної Республіки Крим, територіальні громади - через органи місцевого самоврядування.

У сучасній науковій доктрині підстави для розмежування приватного права від публічного дослідники умовно поділяють на дві групи: (1) матеріальні, що відштовхуються від аспектів, пов'язаних переважно із предметом правового регулювання; (2) формальні, що беруть за основу

\footnotetext{
1 Ленин В. О задачах Наркомюста в условиях новой экономической политики. Полное собрание сочинений / В. Ленин. 5-е изд. Москва, 1964. Т. 44. 411 с.

${ }_{2}$ Мельник Р., Бевзенко В. Загальне адміністративне право : навчальний посібник / за заг. ред. Р. Мельника. Київ, 2014. С. 49.

${ }^{3}$ Цивільний кодекс України: Закон України від 16 січня 2003 р. № 435-IV / Верховна Рада України. Відомості Верховної Ради України. 2003. № 40. Ст. 356.
} 
розмежування особливості способу (методу) регулювання або побудови правовідносин.

Теорії, які використовують матеріальні критерії, залежно від тих елементів предмета правового регулювання, що висуваються на передній план, у свою чергу, також умовно поділяють на концепції: 1) мети (у публічному праві метою $є$ ціле, а окрема особа має вторинне положення, тоді як у приватному праві окрема особа $є$ метою, а ціле (держава) засобом); 2) інтересу (норми публічного права слідують загальному інтересу, а норми права приватного - індивідуальному); 3) волі (розрізнення приватного і публічного права проводиться, виходячи 3 того, чия воля порушується в момент порушення права - воля держави загалом чи воля окремої особи); 4) власне предмета (приватне право визначає майновий стан особи, тоді як публічне право - іiі особистий (немайновий) стан).

Серед теорій, побудованих на формальних критеріях, залежно від уваги до конкретних елементів методу регулювання умовно виділяють концепції: 1) ініціативи захисту (різниця полягає у специфіці судового захисту: публічне право охороняється за ініціативою влади в порядку кримінального або адміністративного судочинства, а приватне право - за ініціативою приватної особи в порядку цивільного судочинства); 2) субординації (публічному праву притаманні відносини влади-підкорення, а приватному відносини рівних суб'єктів; тому для першого характерне однобічне регулювання, а для другого - договір); 3) віднесення (норми публічного права звернені насамперед до носіїв державної влади, а норми приватного права - до приватних осіб); 4) власне методу правового регулювання (акцент робиться на тому, що в публічному праві застосовується прийом юридичної централізації, а у приватному - юридичної децентралізації). ${ }^{4}$

У сучасній юриспруденції найбільш популярними концепціями розмежування публічного i приватного права $\epsilon$ теорії інтересів, субординації і віднесення.

Слабке місце всіх цих теорій полягає в тому, що вони на підставі одного критерію зводять поділ до простої дихотомії, яка не дозволяє врахувати всієї складності і комплексності правової дійсності.

Водночас найбільш зрозумілими та точними виглядають запропоновані вченими-адміністративістами Р. Мельником та В. Бевзенком такі теорії розмежування публічних та приватних правовідносин:

1) теорія субординації (теорія влади-підпорядкування);

2) спеціально-правова теорія;

3) двоступенева теорія.

\footnotetext{
4 Погребняк С. Поділ права на публічне і приватне (загальнотеоретичні аспекти). Державне будівництво та місиеве самоврядування. 2006. № 12. С. 3-17.
} 


\section{1. Теорія субординації (теорія влади-підпорядкування)}

Теорія субординації застосовується насамперед у випадках, коли необхідно встановити правову природу дій публічної адміністрації або юридичного спору, який виник між громадянином і державою. Для класифікації законодавчих приписів вона не застосовується.

Теорія субординації орієнтується на правовідносини, які виникають між їх учасниками. Ця теорія застосовується фактично лише тоді, коли держава (орган) та громадянин протистоять один одному.

Якщо між державою та громадянином виникають відносини влади підпорядкування, то відповідні дії публічної адміністрації або адміністративні акти, які стосуються цих відносин, мають публічноправову природу. Викладене так само діє щодо спорів про право, які стосуються цих відносин. Якщо між державою та громадянином виникають відносини, у яких вони взаємодіють як рівнозначні суб'єкти, дії публічної адміністрації або адміністративні акти матимуть приватноправову природу.

Водночас суб'єкт публічної адміністрації може бути учасником публічно-правових (адміністративних) відносин навіть за відсутності між ним і приватною особою відносин влади - підпорядкування.

\section{2. Спеціально-правова теорія}

До публічного (адміністративного) права, відповідно до цієї теорії, норма права належатиме в тому разі, якщо вона за будь-яких умов іiі застосування уповноважує або зобов'язує винятково суб'єкта публічної адміністрації до певної дії чи рішення. Інші норми належатимуть до приватного права.

Спеціально-правова теорія використовується переважно для розмежування публічно-правових (адміністративних) та приватноправових спорів.

Публічно-правовий спір має місце тоді, коли юридичні приписи, яких стосується спір, належать до публічного права.

Застосування спеціально-правової теорії здійснюється у два логічні етапи: спочатку варто встановити, які саме юридичні приписи є об'єктом юридичного спору. I лише після цього можна перевіряти, чи $є$ вони публічно-правовими (адміністративними).

Основним недоліком спеціально-правової теорії $\epsilon$ те, що вона може застосовуватись лише тоді, коли є очевидним, навколо якої саме норми відбувається спір про право.

\section{3. Двоступенева теорія}

Відправною точкою зазначеної теорії є два основних положення: 
- публічна адміністрація може виконувати покладені на неї обов'язки також у приватноправовій формі;

- публічна адміністрація може втілювати в життя публічно-правові рішення за допомогою приватноправових дій, заснованих на положеннях цивільного права.

Останнє із зазначених положень зумовлює висновок про існування таких правовідносин, у яких мають місце як публічно-правові (адміністративні), так і приватноправові елементи. Саме до таких випадків і застосовується ця теорія.

Двоступенева теорія розмежовує правовідносини залежно від рівнів ухвалення рішення:

- перший рівень (питання «якщо»): рішення суб'єкта публічної адміністрації, якщо він діє, є публічно-правовим;

- другий рівень (питання «як»): вид та спосіб того, як діє публічна адміністрація, можуть бути публічно-правовими (адміністративними) та приватноправовими.

Водночас наявність цієї теорії не $\epsilon$ свідченням того, що в усіх правовідносинах можуть бути виділені два рівні. Ця теорія не свідчить також і про те, що в усіх дворівневих правовідносинах другий рівень завжди буде приватноправовим (це лише можливість). Крім того, зазначена теорія не $\epsilon$ тією теорією, на підставі якої в усіх випадках може здійснюватися розмежування публічного (адміністративного) та приватного права.

Двоступенева теорія застосовується переважно у двох сферах: у сфері надання субвенцій (субсидії, дотації) та у сфері користування публічними установами (об'єкти). ${ }^{5}$

3 огляду на вказане, для точного визначення, чи $є$ відповідні відносини адміністративно-правовими, чи вони $\epsilon$ приватноправовими доцільне застосування комплексного підходу, а саме використання всіх зазначених вище теорій розмежування. Після застосування всіх теорій, шляхом виключення найбільш неможливого, залишиться те, що буде вказувати на правову природу відносин.

Водночас варто зазначити, що на практиці, перед дослідженням правової природи відносин спочатку варто звернутися до нормативно-правових актів, у яких закріплено віднесення певних спорів до конкретної юрисдикції суду. Зокрема, у ст. 19 Кодексу адміністративного судочинства України зазначаються справи в публічно-правових спорах, на які поширюється юрисдикція адміністративних судів. До таких справ належать:

\footnotetext{
5 Мельник Р., Бевзенко В. Загальне адміністративне право : навчальний посібник / за заг. ред. Р. Мельника. Київ, 2014. С. 50-54.
} 
1) спори фізичних чи юридичних осіб із суб'єктом владних повноважень щодо оскарження його рішень (нормативно-правові акти чи індивідуальні акти), дій чи бездіяльності, крім випадків, коли для розгляду таких спорів законом встановлено інший порядок судового провадження;

2) спори щодо прийняття громадян на публічну службу, її проходження, звільнення з публічної служби;

3) спори між суб'єктами владних повноважень щодо реалізації їхньої компетенції у сфері управління, зокрема делегованих повноважень;

4) спори, що виникають стосовно укладання, виконання, припинення, скасування чи визнання нечинними адміністративних договорів;

5) за зверненням суб'єкта владних повноважень у випадках, коли право звернення до суду для вирішення публічно-правового спору надано такому суб'єкту законом;

6) спори щодо правовідносин, пов'язаних із виборчим процесом чи процесом референдуму;

7) спори фізичних чи юридичних осіб із розпорядником публічної інформації щодо оскарження його рішень, дій чи бездіяльності в частині доступу до публічної інформації;

8) спори щодо вилучення або примусового відчуження майна для суспільних потреб чи з мотивів суспільної необхідності;

9) спори щодо оскарження рішень атестаційних, конкурсних, медикосоціальних експертних комісій та інших подібних органів, рішення яких $\epsilon$ обов'язковими для органів державної влади, органів місцевого самоврядування, інших осіб;

10) спори щодо формування складу державних органів, органів місцевого самоврядування, обрання, призначення, звільнення їх посадових осіб;

11) спори фізичних чи юридичних осіб щодо оскарження рішень, дій або бездіяльності замовника у правовідносинах, що виникли на підставі Закону України «Про особливості здійснення закупівель товарів, робіт і послуг для гарантованого забезпечення потреб оборони», за винятком спорів, пов'язаних з укладенням договору з переможцем переговорної процедури закупівлі, а також зміною, розірванням і виконанням договорів про закупівлю;

12) спори щодо оскарження рішень, дій чи бездіяльності органів охорони державного кордону у справах про правопорушення, передбачені Законом України «Про відповідальність перевізників під час здійснення міжнародних пасажирських перевезень»;

13) спори щодо оскарження рішень Національної комісії з реабілітації у правовідносинах, що виникли на підставі Закону України «Про реабілітацію жертв репресій комуністичного тоталітарного режиму 1917-1991 рр.»; 
14) спори із суб'єктами владних повноважень щодо проведення аналізу ефективності здійснення державно-приватного партнерства;

15) спори, що виникають у зв'язку з оголошенням, проведенням та/або визначенням результатів конкурсу з визначення приватного партнера та концесійного конкурсу.

Крім того, юрисдикція адміністративних судів не поширюється на справи:

1) що віднесені до юрисдикції Конституційного Суду України;

2) що мають вирішуватися в порядку кримінального судочинства;

3) про накладення адміністративних стягнень, крім випадків, визначених цим Кодексом;

4) щодо відносин, які відповідно до закону, статуту (положення) громадського об’єднання, саморегулівної організації віднесені до його (іi) внутрішньої діяльності або виключної компетенції.

Адміністративні суди не розглядають позовні вимоги, які є похідними від вимог у приватноправовому спорі і заявлені разом із ними, якщо цей спір підлягає розгляду в порядку іншого, ніж адміністративне, судочинства і перебуває на розгляді відповідного суду.

Велике значення для віднесення того чи іншого спору до юрисдикції суду має і судова практика.

Так, у постанові Верховного Суду від 3 квітня 2019 р. у справі № 727/1002/17 зазначається така правова позиція.

Неправильне поширення юрисдикції адміністративних судів на той чи інший спір тільки тому, що відповідачем у справі є суб'єкт владних повноважень, а предметом перегляду - його акт індивідуальної дії. Визначальною ознакою справи адміністративної юрисдикції є суть (зміст, характер) спору. Публічно-правовий спір, на який поширюється юрисдикція адміністративних судів, $є$ спором між учасниками публічноправових відносин і стосується саме цих відносин.

Натомість визначальні ознаки приватноправових відносин - юридична рівність та майнова самостійність їх учасників, наявність майнового чи немайнового, особистого інтересу суб'єкта. Спір буде мати приватноправовий характер, якщо він зумовлений порушенням приватного права (зазвичай майнового) окремого суб'єкта, що підлягає захисту способом, передбаченим законодавством для сфери приватноправових відносин, навіть тоді, якщо до порушення приватного права призвели владні управлінські дії суб’єкта владних повноважень.

У разі оскарження окремих пунктів ненормативного акта органу місцевого самоврядування про відмову в поновленні договору оренди земельної ділянки, яка $\epsilon$ комунальною власністю, міськрада під час 
здійснення повноважень власника землі $€$ рівноправним суб'єктом земельних відносин.

Отже, суд доходить висновку, що в орендних відносинах виникає спір про цивільне право, оспорювання права оренди на спірні земельні ділянки не має вирішуватися за правилами адміністративного судочинства, адже адміністративний суд позбавлений правових (законодавчих) можливостей установлювати (визнавати) належність права оренди на земельні ділянки. ${ }^{6}$

Цікавою в контексті розмежування публічних відносин від приватних $\epsilon$ постанова Верховного Суду від 14 травня 2019 р. у справі № 918/843/17.

Велика Палата Верховного Суду зазначає, що орган виконавчої влади або місцевого самоврядування у відносинах щодо організації та порядку проведення торгів (тендер) діє як суб'єкт владних повноважень, спори щодо оскарження рішень чи бездіяльності цих органів до виникнення договірних правовідносин між організатором та переможцем цього тендеру належать до юрисдикції адміністративних судів. Проте після укладення договору між організатором конкурсу та його переможцем спір щодо правомірності рішення тендерного комітету підлягає розгляду в порядку цивільного (господарського) судочинства, оскільки фактично зачіпає майнові інтереси переможця торгів. ${ }^{7}$

\section{2. Співвідношення адміністративного та господарського договору у сфері інвестиційної діяльності}

У сфері публічного адміністрування інвестиційної діяльності найбільшу складність у розмежуванні адміністративно-правових від приватноправових відносин становлять укладені із суб'єктом публічної адміністрації договори. Пов'язано це $з$ тим, що частина таких укладених договорів є господарськими договорами, а інша частина належить до адміністративних договорів як однієї з форм адміністративно-правового регулювання (інструменти діяльності публічної адміністрації).

Першочергове у визначенні того, $\epsilon$ договір адміністративним чи господарським, дослідження нормативного визначення поняття «адміністративний договір».

Відповідно до п. 16 ч. 1 ст. 4 Кодексу адміністративного судочинства, адміністративний договір - спільний правовий акт суб'єктів владних повноважень або правовий акт за участю суб'єкта владних повноважень та іншої особи, що грунтується на їх волеузгодженні, має форму договору,

\footnotetext{
6 Постанова Верховного Суду у справі № 727/1002/17. URL: http://reyestr.court.gov.ua/Review/ 81171420 (дата звернення: 03.05.2020).

7 Постанова Верховного Суду у справі № 918/843/17. URL: http://www.reyestr.court.gov.ua/Review/ 81799994 (дата звернення: 03.05.2020).
} 
угоди, протоколу, меморандуму тощо, визначає взаємні права й обов'язки його учасників у публічно-правовій сфері й укладається на підставі закону:

а) для розмежування компетенції чи визначення порядку взаємодії між суб'єктами владних повноважень;

б) для делегування публічно-владних управлінських функцій;

в) для перерозподілу або об’єднання бюджетних коштів у випадках, визначених законом;

г) замість видання індивідуального акта;

г) для врегулювання питань надання адміністративних послуг.

У науці адміністративного права виділяють такі ознаки адміністративного договору:

1) одним з учасників адміністративного договору обов'язково є суб'єкт владних повноважень;

2) змістом адміністративного договору $\epsilon$ права й обов'язки його учасників у публічній правовій сфері.

3) укладається на підставі закону, тобто право суб'єкта владних повноважень укласти адміністративний договір має бути передбачене саме законом, а не підзаконними актами;

4) реалізується зазвичай на нормах адміністративного права;

5) спричиняє безпосереднє настання юридичних наслідків у вигляді виникнення, зміни та припинення правовідносин (меморандум про співпрацю), виникнення зміни, припинення прав i обов'язків його учасників (договори про розстрочення та відстрочення грошових зобов'язань або податкового боргу платника податків) у публічній сфері;

6) метою адміністративного договору є задоволення публічних інтересів;

7) адміністративний договір оформлює ті суспільні відносини, які входять до предмета адміністративного права. ${ }^{8}$

Питання розмежування та дослідження природи адміністративного договору здебільшого пов'язано із правозастосовною діяльністю, зокрема 3 діяльністю адміністративних судів.

Так, особливої важливості у сфері інвестиційної діяльності набуває питання відмінності між господарським договором на здійснення інвестиційної діяльності й адміністративним договором у сфері регулювання адміністративної діяльності.

Правильне розуміння сутності адміністративного договору дозволяє віднести той чи інший договір до юрисдикції господарських або адміністративних судів.

8 Завальна Ж. Порівняльний аналіз адміністративного та цивільного договорів. Право Украӥни. 2007. № 3. C. 135-139. 
До речі, розширене нормативне визначення поняття «адміністративний договір», яке містить мету такого договору та приклади суспільних відносин, які врегульовуються таким договором, у Кодексі адміністративного судочинства України набуло чинності 15 грудня 2017 р., на підставі Закону України № 2147-VIII від 3 жовтня 2017 p.

До цього в Кодексі адміністративного судочинства України було закріплено таке визначення поняття «адміністративний договір» - дво- або багатостороння угода, зміст якої становлять права й обов'язки сторін, що випливають із владних управлінських функцій суб'єкта владних повноважень, який є однією зі сторін угоди.

Отже, до набуття чинності змін до Кодексу адміністративного судочинства суди послуговувалися здебільшого доктриною адміністративного права та власним розумінням поняття «адміністративний договір».

Яскравим прикладом таких судових умовиводів $\epsilon$ викладений у постанові Верховного Суду, за результатом розгляду справи № 903/605/17, висновок стосовно того, що договір про організацію перевезень пасажирів на приміських та міжміських внутрішньообласних автобусних маршрутах, укладений із Департаментом інфраструктури та туризму обласної державної адміністрації, $\epsilon$ адміністративним у зв'язку з тим, що він фактично замінює дозвіл на перевезення, який, у свою чергу, $\epsilon$ індивідуальним актом. ${ }^{9}$ Відсутність на момент укладання договору нормативної чіткості поняття «адміністративний договір» призвела до дискусій та неоднакової позиції серед самих суддів, які здійснювали розгляд вказаної справи. Так, в окремій думці від 4 червня 2019 р. суддів Великої Палати Верховного Суду С. Бакуліної, Ю. Власова, О. Кібенко, Л. Рогач, В. Уркевич було зазначено, що справа повинна була розглядатися в порядку господарського судочинства, а сам договір перевезення пасажирів не можна вважати адміністративним. На обгрунтування своєї позиції судді вказали, якщо суб'єкти (зокрема, орган державної влади, органи місцевого самоврядування, їхні посадові чи службові особи), хоча б і на реалізацію своїх повноважень, вільно укладають договір відповідно до норм Цивільного кодексу України, під час укладання такого договору його сторони вільно домовляються про зміст та обсяг прав і обов'язків за договором, можуть відмовитись від його укладання, то такий договір $\epsilon$ цивільним (господарським), але не адміністративним, оскільки у змісті цього договору відсутні відносини влади і підпорядкування, що є обов'язковими для адміністративного договору, а суб'єкти такого договору виступають як рівні один з одним. ${ }^{10}$

\footnotetext{
9 Постанова Верховного Суду у справі № 903/605/17. URL: http://www.reyestr.court.gov.ua/Review/ 82885681 (дата звернення: 03.05.2020).

${ }^{10}$ Окрема думка суддів Верховного Суду у справі № 903/605/17. URL: http://www.reyestr.court.gov.ua/Review/82885659 (дата звернення: 03.05.2020).
} 
Відсутність однозначного розуміння того, що $є$ адміністративним договором та природи відносин, які склались між його сторонами, призводила до численних юрисдикційних помилок суддів.

Так, до адміністративних договорів, укладених у сфері інвестиційної діяльності, суд відніс договір про реалізацію інвестиційного проєкту (постанова Одеського окружного адміністративного суду у справі № 815/1978/14). ${ }^{11}$

Водночас віднесення такого договору до адміністративного неправильне. Наслідком такої помилки суду стало подальше скасування судом касаційної інстанції його рішення. Так, за результатом розгляду справи № 815/1978/14 Верховний Суд у складі колегії суддів Касаційного адміністративного суду дійшов висновку, що у справі, що розглядається, спірні правовідносини виникли між учасниками справи у зв'язку з укладенням договорів про реалізацію інвестиційного проєкту та про оренду землі, а отже, існує спір про право, що виключає можливість розгляду цієї справи за правилами адміністративного судочинства. Такий спір має вирішуватися в порядку господарської юрисдикції, оскільки виникає спір про право користування земельною ділянкою. ${ }^{12}$ У зв'язку із цим Верховний Суд скасував попереднє рішення суду апеляційної інстанції, закрив провадження у справі через порушення правил юрисдикції адміністративних судів.

Цікавою є постанова Сьомого апеляційного суду, у якій Суд під час розгляду та вирішення справи № $120 / 1435 / 19-\mathrm{a}^{13}$ зробив такий висновок: «Метою адміністративних договорів здебільшого є реалізація публічних інтересів, в той час як метою більшості приватноправових договорів виступає індивідуальний інтерес. Для сторін адміністративного договору свобода вступати чи не вступати в договірні відносини не має характеру абсолютного принципу, що властиво приватному праву. Укладення адміністративного договору з боку державного органу є одночасно правом і обов'язком (предметна компетенція). Можливість на власний розсуд під час укладення адміністративних договорів обирати певний варіант поведінки є обмеженішою, ніж при укладенні цивільних чи господарських договорів. Це обумовлено імперативним характером адміністративноправових норм. Отже, зміст адміністративного договору відрізняє його від господарських угод, у яких відносини грунтуються на юридичній рівності сторін, вільному волевиявленні та майновій самостійності».

\footnotetext{
11 Постанова Одеського окружного адміністративного суду у справі № 815/1978/14. URL: http://www.reyestr.court.gov.ua/Review/57489230 (дата звернення: 03.05.2020).

12 Постанова Верховного Суду у справі № 815/1978/14. URL: http://www.reyestr.court.gov.ua/Review/ 75958342 (дата звернення: 03.05.2020).

13 Постанова Сьомого апеляційного суду у справі № 120/1435/19-a. URL: http://www.reyestr.court.gov.ua/ Review/86997320 (дата звернення: 03.05.2020).
} 
Незважаючи на те, що нині визначення поняття «адміністративний договір», що закріплено в Кодексі адміністративного судочинства України, $\epsilon$ ширшим, ніж до змін 2017 р., під час визначення правової природи відносин варто користуватися не тільки нормативним актом, а й правовою доктриною, оскільки саме розуміння сутності адміністративного договору, розуміння критеріїв розмежування адміністративно-правових відносин від приватноправових унеможливить помилки у визначенні юрисдикції суду, якими б складними та неоднозначним не були юридичні спори.

Під час розмежування адміністративного договору та приватноправового договору необхідно базуватися на сучасному розумінні суті та меж юридичного регулювання адміністративного права, а також враховувати таке. Суб'єктний склад учасників договірних відносин не $\epsilon$ тією ознакою, за допомогою якої можна однозначно визначитися із правовою природою договору. Натепер суб'єкти публічної адміністрації можуть укладати один 3 одним як цивільно-правові, так і адміністративно-правові договори. Як однозначний критерій розмежування названих договорів не може використовуватися i така ознака, як «наявність відносин влади i підпорядкування між учасниками договору», оскільки велика кількість адміністративно-правових відносин не $\epsilon$ владними за своїм характером, отже, адміністративний договір не обов'язково буде характеризуватися владними рисами. Не $є$ визначальним для встановлення юридичної природи і те, що через договір виконується публічне завдання (задовольняється публічний інтерес). Суб'єкт публічної адміністрації може досягати публічних цілей також шляхом укладання приватноправового договору.

Цікавого висновку доходять учені-адміністративісти Р. Мельник i В. Бевзенко, які зазначають, що про адміністративний договір необхідно вести мову тоді, коли:

- він спрямований на реалізацію норм адміністративного права, отже, на виникнення (зміну, припинення) адміністративно-правових відносин;

- покладені ним зобов'язання або розпорядження, які реалізуються в його межах, мають адміністративно-правовий характер.

3 огляду на це адміністративним уважається договір, що спрямовується на реалізацію адміністративно-правової норми; який містить зобов'язання видати адміністративний акт або вчинити іншу адміністративну дію; що має своєю основою закріплені нормами адміністративного права обов'язки або права приватної особи. ${ }^{14}$

Ураховуючи вказане, договори, укладені між суб'єктом публічної адміністрації та приватною особою, спрямовані на реалізацію

\footnotetext{
14 Мельник Р., Бевзенко В. Загальне адміністративне право : навчальний посібник / за заг. ред. Р. Мельника. Київ, 2014. С. 292-293.
} 
інвестиційних проєктів, не можуть відноситись до адміністративних договорів. Такі договори є суто приватноправовими. Такі договори можуть укладатися за результатом публічних процедур (конкурси, тендери тощо), водночас це не може призводити до визнання їх адміністративними, оскільки такі договори не мають ознак адміністративного договору.

3 урахуванням вищенаведеного, серед прикладів адміністративних договорів в інвестиційній діяльності можна назвати такі:

- договір про розстрочення грошових зобов'язань, укладений на виконання рішення податкового органу (постанова Верховного Суду у справі № 826/8032/17 ${ }^{15}$ );

- мирова угода, укладена на підставі ст. 521 Митного кодексу України (припинення провадження шляхом компромісу, за відсутності в діях особи, яка вчинила порушення митних правил, ознак злочину);

- договір про передачу міжбюджетного трансферту на реалізацію інвестиційного проєкту.

\section{ВИСНОВКИ}

Отже, розмежування адміністративно-правових відносин від приватноправових має вагоме значення під час вирішення питання про віднесення того чи іншого спору до юрисдикції суду, зокрема адміністративного. Найбільш дієвий алгоритм визначення юрисдикції спору такий: 1) перевірити в нормативно-правових актах, чи не закріплено розгляд спору за юрисдикцією певного суду; 2) здійснити розмежування за предметом спору; 3 ) переходити до розмежування за суб'єктом.

Крім того, варто зазначити, що договори, спрямовані на реалізацію інвестиційних проєктів, зазвичай є господарськими договорами. Водночас адміністративним варто вважати договір, що спрямовується на реалізацію адміністративно-правової норми; який містить зобов'язання вчинити адміністративну дію; укладається замість індивідуального (адміністративного) акта; що має своєю основою закріплені нормами адміністративного права обов'язки або права приватної особи.

\section{АНОТАЦІЯ}

Питання розмежування адміністративно-правових відносин від приватноправових у сфері публічного адміністрування інвестиційної діяльності має велике значення. На практиці трапляються випадки, коли складно визначити, які саме відносини виникають між державним підприємством, місцевою державною адміністрацією і юридичною особою

15 Постанова Верховного Суду у справі № 826/8032/17. URL: http://www.reyestr.court.gov.ua/ Review/82315560 (дата звернення: 03.05.2020). 
під час укладання інвестиційних договорів. Ще складнішим виглядає питання стосовно того, які договори у сфері інвестиційної діяльності, однією зі сторін за якими є суб'єкт публічної адміністрації, належать до адміністративних, а які до господарських.

Результатами дослідження $\epsilon$ зазначення теорій, які допомагають здійснити розмежування приватноправових відносин від публічноправових. Крім того, під час дослідження були проаналізовані рішення судів із метою визначення типових помилок під час віднесення договорів, укладених із суб'єктом публічної адміністрації, до адміністративних. Отже, дослідження спрямоване на з'ясування критеріїв і теорій, використання яких дозволяє правильно визначити, $€$ відносини приватноправовими чи вони публічно-правові, що в подальшому дозволяє правильно віднести спір до юрисдикції конкретного суду.

\section{ЛІТЕРАТУРА}

1. Ленин В. О задачах Наркомюста в условиях новой экономической политики. Полное собрание сочинений / В. Ленин. 5-е изд. Москва, 1964. T. $44.411 \mathrm{c}$.

2. Мельник Р., Бевзенко В. Загальне адміністративне право : навчальний посібник / за заг. ред. Р. Мельника. Київ : Ваіте, 2014. 376 с.

3. Цивільний кодекс України : Закон України від 16 січня 2003 р. № 435-IV / Верховна Рада України. Відомості Верховної Ради України. 2003. № 40. Ст. 356.

4. Погребняк С. Поділ права на публічне і приватне (загальнотеоретичні аспекти). Державне будівництво та місиеве самоврядування. 2006. № 12. C. 3-17.

5. Постанова Верховного Суду у справі № 727/1002/17. URL: http://reyestr.court.gov.ua/Review/81171420 (дата звернення: 03.05.2020).

6. Постанова Верховного Суду у справі № 918/843/17. URL: http://www.reyestr.court.gov.ua/Review/81799994 (дата звернення: 03.05.2020).

7. Завальна Ж. Порівняльний аналіз адміністративного та цивільного договорів. Право Украӥни. 2007. № 3. С. 135-139.

8. Постанова Верховного Суду у справі № 903/605/17. URL: http://www.reyestr.court.gov.ua/Review/82885681 (дата звернення: 03.05.2020).

9. Окрема думка суддів Верховного Суду у справі № 903/605/17. URL: http://www.reyestr.court.gov.ua/Review/82885659 (дата звернення: 03.05.2020).

10. Постанова Одеського окружного адміністративного суду у справі № 815/1978/14. URL: http://www.reyestr.court.gov.ua/Review/57489230 (дата звернення: 03.05.2020). 
11. Постанова Верховного Суду у справі № 815/1978/14. URL: http://www.reyestr.court.gov.ua/Review/75958342 (дата звернення: 03.05.2020).

12. Постанова Сьомого апеляційного суду у справі № 120/1435/19-а. URL: http://www.reyestr.court.gov.ua/Review/86997320 (дата звернення: 03.05.2020).

13. Постанова Верховного Суду у справі № 826/8032/17. URL: http://www.reyestr.court.gov.ua/Review/82315560 (дата звернення: 03.05.2020).

Information about author:

Zhukov M. S.,

Postgraduate Student

Zaporizhzhya National University 66, Zhukovsky str., Zaporizhzhya, 69600, Ukraine 